\title{
Students' Ability to Generate Mathematical Concept Ideas Through Somatics, Auditory, Visual, and Intellectual Approach of Students (Madrasah Ibtidaiyah Negeri 6 North Aceh)
}

\author{
Samsul Bahri ${ }^{1, *}$ Husaini $^{2,}$ Nurul Akmal ${ }^{3}$ \\ ${ }^{1,2,3}$ Fakultas Tarbiyah dan Ilmu Keguruan IAIN Lhokseumawe, Indonesia \\ "Corresponding author. Email: sison.bahri@gmail.com
}

\begin{abstract}
The idea of fundamental mathematical concepts used by students in finding formal mathematical forms are the context of fact and science through the SAVI approach (Somatics, Auditory, Visual, Intelectual). The purpose of this research is to know the ability of students to build ideas for mathematical concepts in fractional materials. The this study found that of the study Show (1) The application of SAVI learning approach has been able to improve the ability of MI students to produce the idea of mathematical concepts in fractional material. (2) The idea of mathematical concepts in the students was an early-capacity of $85.4 \%$, while the students had an early initial of $61.7 \%$, while students campaigsed for a low increase in the idea of the mathematical concept not increasing. (3) The ability of students to form students' mathematical concept ideas, namely restating a concept, presenting the concept in various forms of representation, and applying the concept in problem solving to fraction material is in the very good category for students who have a high initial ability value, namely $78.4 \%$. While students who have moderate and low initial abilities have no interaction and are in the medium category, namely $51.3 \%$ and $46.3 \%$.
\end{abstract}

Keywords: Mathematical Concept Ideas, Application of SAVI (Somatics, Auditory, Visual, Intellectual)

\section{INTRODUCTION}

Mathematics has an important role in improving quality of human resources in the era of evolution 4.0. The importance of learning mathematics in Madrasah Ibtidaiyah schools is supported By Indonesian Regulation, Number 20, and year 2003 about National Education System. It is specifically stated in article 37 which describes that mathematics is one of the compulsory subjects for students at the primary and secondary levels. According to the Ministry of National Education in 2006, mathematics subjects aim to encourage students to have abilities of: students who have ability of: (1) Using reasoning on patterns and traits; (2) Solving a problem indicates a challenge; (3) Communication is a process of giving and conveying meaning an effort to create sharing understanding; (4) Understanding mathematical concepts.
According to Zuliana [1], there are seven indicators of understanding mathematical concepts: (1) restating a concept, (2) classifying objects based on to certain properties, (3) providing examples and non-examples, (4) presenting concepts in various forms of representation mathematics, (5) developing the necessary or sufficient conditions for a concept, (6) utilizing, using, and selecting certain procedures or operations, (7) applying the concept. In however there are still many students having problems regarding mathematical concepts, this is stated by Dahma, Suarjana and Suartama [2] there were still many students who had difficulty solving questions, identifying what was being asked in the questions, understanding language, and calculations. Students cannot develop and solved a new mathematics problem because they are just memorizing formulas, imitating the same problems, so that the teacher gave different 
questions, many students made incorrect calculations and incorrect answer [3].

One of the challenges in education today is how to teach mathematics meaningfully. In Brownell and Van Engen's theory [4], student must see the meaning and need for practicing of what they learn in mathematics. The process of learning mathematics in Madrasah Ibtidaiyah is not just memorizing and doing worksheet, but it focus on understanding and meaningful learning

This is in line with Freudenthal's opinion [5] who state that mathematics learning must be connected and closed to the real world of student. Interactions as teachers pursue instructional goals [6]. Mathematics learning also must be relevant to values of life [7]. Therefore, a change is needed to achieve meaningful learning. Challenge for educators in learning needs to provide a real context of facts in the real world and close to student to understand mathematical concepts and provide opportunities to develop ideas.

It means that educators should be able to understand the relationship between mathematical concept with the real world, and how to learning models to solve the problem in mathematics. Grigoras [8] says that Modelling always involves mathematising, which is considered as activity of observing, sructuring and interpreting the world by means of mathematical models. That modeling in mathematics learning as an activity of observing, organizing and interpreting the world by means mathematical models.

For meaningful and fun mathematics learning, educators should be able to use context that is appropriate for the age of the student in Madrasah Ibtidaiyah, namely finding forms of formal mathematics that come from the context of facts and science. In this case, the ability to demonstrate the addition and subtraction of fractions in a mechanism or procedure is not enough, the main goal of teaching mathematics is to develop students' abilities to generate mathematical conceptual ideas and to realize how importance mathematics in real life [9]. According to Treffers in Grigoras [8], in educational context, the idea of two ways of mathematising, which led to reformulation by Freudenthal in terms of horizontal and vertical mathematisation. in the context of education.

SAVI is an approach that emphasizes on escalating learning process by maximizing all students' senses. Somatic means physical activity. Auditory means learning through listening, speaking, presenting, expressing opinions, arguing, and responding. Visual means using the eye senses through drawing, reading, observing, demonstrating, using media and props. Meanwhile, intellectual means learning to use thinking skills, practicing using them through reasoning. Learning must be by investigating, identifying, discovering, constructing, creating, solving problems, and applying [10]. SAVI learning approach is a combination of physical movements and intellectual activities that also involves all students' senses. Hence, it could help students to connect real objects to mathematical conceptual ideas.

The research question in this study is "How is the ability Madrasah Ibtidaiyah Students in building mathematical conceptual ideas on the matter of addition and subtraction of fractions?". Based on the formulation of the problem, the purpose of this study is "To find out the ability of madrasah ibtidaiyah students in building mathematical conceptual ideas on the matter of addition and subtraction of fractions".

\section{RESEARCH METHODS}

This study employed qualitative method in gathering data. Qualitative method aims to describe and analyse phenomena, events, activities, social, attitudes, beliefs, perceptions, thoughts of people individually or in groups. [11]. According to Bogdan and Taylor [12], qualitative methods is research procedures that produce descriptive data in the form of oral or written words from people and observable behavior.

Hence, qualitative method focuses on that qualitative research focuses on data processing efforts in the form of words that are predictive, interpretative, and factual. This research is a type of field research and included in pure research because this research is carried out by conducting direct field research

\section{RESULTS AND DISCUSSIONS}

This research was conducted at MIN 6 North Aceh in second semester of the 2018/2019 academic year. The research took place sixteen times. The first meeting was pretest and the $16^{\text {th }}$ meeting was posttest. This research is designed to be three activities that will see how students used mathematical conceptual ideas to solve problem in the addition and subtraction operations material of fractions through the SAVI approach: Activity 1, Pictures and Videos In this activity, students are given various pictures and videos in the facts context and science about fractions. Students are provided with guidance and guided by pictures and videos to conclude what they learned using their own language. Activity 2 , Solve the problems, In this activity, students will be given problems in the form of stories presented in the students's worksheets. Then students are required to find solutions to these problems, Activity 3, Playing with real objects, In this activity, students played with real objects related everyday problems about fractions and explain how to solve them. Imply to rethink unit rate as part of a partitive division with fractions [13].

In the series of activities above, the researcher found that in each activity that had been designed, students used mathematical concepts. In the learning process 
students bring various ideas from the process in group discussion during the activity.

After conducting those activities, it can be understood that learning with the application of the SAVI learning approach has been able to improve the ability of Madrasah Ibtidaiyah students in generating mathematical concept ideas on fraction material. The increase in the ability to generate mathematical concept ideas in terms of students' initial abilities (low, medium, and high), it can be seen that the mathematical concept ideas of students with high initial abilities are $85.4 \%$, students with moderate initial abilities are $61.7 \%$, students with low initial abilities had no increase significantly. The ability of students to form students' mathematical concept ideas, namely restating a concept, presenting the concept in various forms of representation, and applying the concept in problem solving to fraction material is in the very good category for students who have a high initial ability value, namely $78.4 \%$. While students who have moderate and low initial abilities have no interaction and are in the medium category, namely $51.3 \%$ and $46.3 \%$.

Based on data analysis through tests and non-tests, it can be seen that students who have high initial abilities are able to understand the concept of fraction material and can improve the concept of fractions, while students with moderate and low initial skills does not increase mathematical concept ideas, this seems that students have not been able to develop the requirements. which is needed to solve the problem because students are still fixated on the rote formula. Students only imitate the solution given by the teacher and have difficulty finding problems with different solutions. Loscalzo et al. [14] also found that "mathematics learning achievement of students is better and meaningful after optimizing all the senses in the learning which includes elements of SAVI.

\section{CONCLUSIONS AND SUGGESTIONS}

\subsection{Conclusions}

This study found that of the study show (1) The application of SAVI learning approach has been able to improve the ability of MI students to produce the idea of mathematical concepts in fractional material. (2) The idea of mathematical concepts in the students was an early-capacity of $85.4 \%$, while the students had an early initial of $61.7 \%$, while students campaigned for a low increase in the idea of the mathematical concept not increasing. (3) The ability of students to form students' mathematical concept ideas, namely restating a concept, presenting the concept in various forms of representation, and applying the concept in problem solving to fraction material is in the very good category for students who have a high initial ability value, namely $78.4 \%$. While students who have moderate and low initial abilities have no interaction and are in the medium category, namely $51.3 \%$ and $46.3 \%$.

\subsection{Suggestions}

1) Educators, both teachers and researchers, to further develop instructional designs, 2) The results of this study indicate that students learned according to the research design that has been made. Therefore, to further design the introduction of flat shapes at the madrasah ibtidaiyah level, 3) It needs to be developed in other mathematics material to motivate and train students in developing students' mathematical concept ideas, 4) For the next researchers, they could design more comprehensive learning. Hence, not only introduction of basic concepts and implementation of leading concepts that students learnt, the introduction of basic concepts and implementation of leading concepts. The next researcher should motivate and pay attention to the treatment, especially for low-ability students.

\section{REFERENCES}

[1] E. Zuliana, Penerapan Inquiry Based Learning berbantuan Peraga Manipulatif dalam Meningkatkan Pemahaman Konsep Matematika pada Materi Geometri Mahasiswa PGSD Universitas Muria Kudus, Jurnal Pendidikan, vol. 8, no. 1, 2017, pp. 35-43.

[2] I. M. A. Dharma, I. M. Suarjana, and I. K. Suartama, Analisis Kemampuan Menyelesaikan Soal Cerita pada Siswa Kelas IV Tahun Pelajaran 2015/2016 Di SD Negeri 1 Banjar Bali, e-Journal PGSD Universitas Pendidikan Ganesha, vol. 4, no. 1, 2016, pp. 1-10.

[3] N. A. Mukrimatin, Murtono, and S. Wanabuliandari, Pemahaman Konsep Matematika Siswa Kelas V SD Negeri Rau Kedung Jepara Pada Materi Perkalian Pecahan, Jurnal Ilmiah Pendidikan Matematika, vol. 1, no. 1, 2018, pp. $67-$ 71.

[4] Karso, Pendidikan Matematika, Jakarta: Universitas Terbuka, 2007.

[5] M. Van den Heuvel-Panhuizen, Mathematics Education in the Netherlands: A guide tour, Utrecht: Utrecht University, 2000.

[6] M. T. Tatto, M. C. Rodriguez, M. D. Reckase, W. M. Smith, K. Bankov, and J. Pippin, The FIRSTMATH Study: Concepts, Methods, and Strategies for Comparative International Research in Mathematics Education, in: The First Five Years of Teaching Mathematics (FIRSTMATH), 2020, pp. 1-20, Springer, Cham.

[7] R. D. Agustin, M. Ambarawati, and E. D. Kartika Development of mathematical learning instruments based on ethnomathematics in character education learning, International Journal on Teaching and 
Learning Mathematics, vol. 1, no. 1, 2018, pp. 2430.

[8] R. Grigoras, Modelling in Environments without Numbers - A case study, in: Proceedings of CERME 6, 2010, pp. 2206-2215, Lyon France.

[9] R. Kossak, What Is a Number?, In: Mathematical Logic, Springer Graduate Texts in Philosophy, 2018, vol 3., pp. 33-39, Springer, Cham.

[10] D. Meier, The Accelerated Learning Handbook: Panduan kreatif dan efektif merancang program pendidikan dan pelatihan, Bandung: Kaifa, 2002.

[11] N. S. Syukmadinah, Metode Penelitian Pendidikan, Bandung: Remaja Rosdakarya, 2013.
[12] L. J. Moleong, Metodologi Penelitian Kualitatif, Bandung: Remaja Rosdakarya, 2013.

[13] K. Wahyu, T. E. Kuzu, S. Subarinah, D. Ratnasari, and S. Mahfudy, Partitive Fraction Division: Revealing and Promoting Primary Students' Understanding, Journal on Mathematics Education, vol. 11. No. 2, 2020, pp. 237-258.

[14] L. W. Loscalzo, R. W. Granger, G. A. R. Johnston, A. C. Paladini, Central nervous system depressant action of flavonoid glycosides, European Journal of Education, vol. 539, 2011, pp. 168-176. 